\title{
Democracy and Choice: Do These Mean Anything to the Average Ghanaian?
}

\author{
Ishmael Norman ${ }^{1,2,3}$ \\ ${ }^{1}$ School of Public Health, University of Health and Allied Sciences, Hohoe Campus, Ho, Ghana \\ ${ }^{2}$ Institute for Security, Disaster and Emergency Studies, Sandpiper Place, Langma, Ghana \\ ${ }^{3}$ African Academy for Environmental Health (AAEH), University of Malawi, Zomba, Malawi \\ Email: ishmael_norman@yahoo.com
}

How to cite this paper: Norman, I. (2017). Democracy and Choice: Do These Mean Anything to the Average Ghanaian? Advances in Applied Sociology, 7, 115-135. https://doi.org/10.4236/aasoci.2017.73007

Received: January 14, 2017

Accepted: March 28, 2017

Published: March 31, 2017

Copyright $\odot 2017$ by author and Scientific Research Publishing Inc. This work is licensed under the Creative Commons Attribution International License (CC BY 4.0).

http://creativecommons.org/licenses/by/4.0/

\section{(c) (i) Open Access}

\begin{abstract}
The concept of "African democracy" invokes James and Stuart Rachels' (2003) treatise against "Cultural Relativism". That is to say, it is generally assumed that there is democracy relative to Africa and therefore, there is a concept of "African Democracy Relativism". Due to this, democracy in Africa oughts to be different from democracy everywhere else. "Choice" as an ethical value subsists and emanates from autonomy and freedom. When people are free in the democracy, they also have the freedom of "choice" in their functionings. There are many limitations on the right to choose in Africa due to the general limitations placed on freedoms. This paper proposes that there is but one type of democracy in the world, which offers individuals the same kind of freedom of choice and wellbeing, provided it is also accepted that the African is an indivisible part of the universal man or woman. What may have given rise to the erroneous concept of an "African democracy type" is the general assumption that Africa is familiar and understands democratic principles. It was further mistakenly assumed that Africa considered all human beings as equal based on some resplendent intellectual expositions on democracy, which was accepted and known to all. Therefore, all had equal rights, freedom of choice and privileges before the law and man, and that "due process" was part of the mundane administration of justice articulated in a systematic and reviewable medium such as a tablet, stone, book or film or other archival systems. Africa's unwritten history is subject to the revisionist manipulation, prevarication, and unsupported by the cultural norms of the respective nations. These concepts as used in this paper would be defined and discussed accordingly and present a different view point on this matter, using Ghana as a case.
\end{abstract}

\section{Keywords}

Democracy, Choice, Cultural Relativism, Democratic Relativism, African Democracy, Ghana 


\section{Introduction}

"In democracies, where there is never much difference between one citizen and another and where in the nature of things, they are so close that there is always a chance of their all getting merged in a common mass, a multitude of artificial and arbitrary classifications are established to protect each man from the danger of being swept along in spite of himself with the crowd."

(Tocqueville, Democracy II, 1835:783; in Macfarlane, 1995)

\subsection{Ghana's Democracy: An Off-Shoot of Athenian Democracy}

It is submitted in this paper that in the modern day, Ghana's democracy and for that matter, all of Africa's, are part and parcel of the democratic tradition of the world inherited from Athenian sources of ancient Greece. Each nation's democratic practices are modified by experience, struggle and constitutional provisions over time, although democracy comes late to Ghana and Africa (Boahen, 1966; Fayemi, 2009; Raaflaub et al. 2007; Fleck \& Hanssen, 2002; Wallace, 2007). In this paper, it is, therefore, assumed that democracy is originated from ancient Athens, despite the competing claims by other researchers and historians that it originated severally from Egypt (Raaflaub et al. 2007).

This paper is not about the development of government by the traditional rulers or chiefs in the gold coast, and later Ghana, or those of other African nations (IEA, 2010). The paper is about democracy in Ghana and how the concept is translated in the daily lives of the people of the nation, although cross-referencing to other nations in the African continent is made from time to time. The author started the investigation of democracy in Ghana by describing the type of governance system that was practised in Ghana prior to the paradigm shift in governance from the conventional to modern system of government based on the rule of law.

\subsection{Traditional Rule and the Advent of Democratic Governance in Ghana}

Although it is recognized that traditional rulers have been governing the area now called Ghana for a long time, the type of rule they conducted could not be considered as democracy, no matter how charitable one wishes to be about the matter. Speaking about the role of traditional rulers in the gold coast and then in Ghana, the Okyenhene, (Paramount Chief), His Majesty, Osagyefo Amoatia Ofori Panyin said that:

Traditional governance in our country dates back at least five hundred years and the typical pre-colonial state or kingdom was deliberately organized into a decentralized political system for efficient administration. The state [Oman in Akan] structure was, as elsewhere, pyramidal comprising communities categorized according to size-hamlets, villages, towns and cities-and at the helm was the king or sovereign, called (Paramount Chief), Omanhene in Akan. Each community had their own overlord or overseer, 
called Odikro or simply Ohene in Akan depending on size and influence. The election or selection of a ruler, enstoolment was by a well-acknowledged hereditary process accepted and respected by all citizens. The ruler, once in office, was supported by a court of servers and a council to advise, to make and interpret laws, to impose taxes, and to wage wars. The abovedescribed governance system has not changed for centuries and is still observed today (IEA, 2010: p. 2).

With deep reverence and respect, the selection of chiefs then and today is a closed, very secretive process which is not opened to popular participation. If the system was based on democratic principles, the king makers, like an electoral college in other climes, would have been elected or appointed by the people as their representatives. In Ghana and in other nations, king makers attain that status as part of hereditary legacy.

There were no checks and balances in relation to the conduct of the chiefs and powerful traditional men and women. Many of our local chiefs then as it is now, were not ethical people, more so because they saw themselves as absolute rulers with absolute powers. The chiefs were not answerable to anyone but a few men and women of the palace. For example, instead of rehabilitating offenders, many of our chiefs "sold criminals into slavery as punishment". The historian Adu Boahen wrote that "though punishment of malefactors by selling them as slaves was not new in Africa, with the beginning of the slave trade this practice became grossly abused. Many kings formed the habit of punishing any and every offence by enslaving the accused". The kings dreamt up conspiracy theories and finger-pointed alleged perpetrators of make-believe coups, and rounded up alleged ring leaders for sale as slaves. This kind of behavior does not happen in a government of democracy but rather in a government run by criminal impulses and perversions (Boahen, 1966: p. 110; Fayemi, 2009).

Other researchers on this topic and associated topics to democracy are not so charitable in expressing their frustration conducting scientific or forensic analyses of the interplay of democracy and the rulers of the past. Edigheji O. (2005) opened his inquiry into democracy and development with the below salvo.

The history of the post-independent African state is that of monumental democratic and developmental failures. The few exceptions to this have been Botswana and Mauritius, and to a degree, democratic South Africa. After almost four and a half decades of independence, most countries on the continent are characterised by underdevelopment. The evidence for this state of underdevelopment can be found in any social and economic indicators one cares to examine.

At any rate, this paper is also not about the formalized local government system in Ghana alluded to earlier by others, which to all intents and purposes, may date back to the "kamikaze" bond of 1844 between the British and the natives (IEA, 2009; Boahen, 1966). 
To the surprise of the natives and their leaders, the bond allowed the British colonial administrator to levy taxes and other tolls on the people. At this moment, the chiefs realized, they could not collect taxes again and without funds to carry out their projects, the power of the chiefs was diluted and the institution of chieftaincy suffered irreparable damage to its status and image. The authority of the chiefs was further weakened in 1874, when colonial rule was formally imposed on the Gold Coast (Boahen, 1966). About twelve years later, the British Bank of West Africa was formed in 1886 to mop up sovereign revenues which were been collected from the natives. The British Bank of West Africa subsequently morphed into the Standard Chartered Bank of today. It is interesting to note that, the bond was signed (meaning thumb-printed) between the uneducated and definitely unsophisticated natives in the ways of the Western world, native personalities who did not possess the tools to distinguish a contract from a hymn and the British agents who could. The British representatives were educated and savvy about what they wanted from the natives. When the operationalization of the bond began, there was a great deal of angst on the part of the natives, but on the part of the British, they knew they had the natives exactly where they wanted them: powerless and financially decimated (Boahen, 1966). The British colonial administrators had no moral or ethical qualms about entering into a written contract with a group of natives who were not able to read and write and who did not appreciate the legality of a contract. Even though the British did not put a gun to the head of the native chiefs to "thumb print" the bond of 1844 to seal and authenticate it, the natives' chief may have concluded that their interest was also being taken care of by the colonials perhaps, paternalistically (Obeng, 1986; Arhin et al. 1992; Combs et al., 1995). It is quite worrisome to try to analyse why the native leadership actually would sign a contract which they did not really understand because they did not understand the language of the contract, it should be assumed that they did not have capacity.

It appears, pride and egoism, which, coupled with ambivalence and a general lack of responsibility to the people over whom they ruled, contributed to their signing this most unfavourable bond. But from that day forward, deceit as a function of governance was deterministically introduced into the heart of the deal between government and the people in the Gold Coast, and later Ghana. But, with the incoming revenue, came power and British intransigency in governance in the Gold Coast (Boahen, 1966; Burton, 1984; Obeng, 1986; Arhin et al. 1992; Combs et al. 1995; IEA, 2010).

The Gold Coast Ordinance of 1883 empowering the chiefs to maintain law and order was too little too late in terms of the acknowledgement of the natural rights of the chiefs to rule over their own people (Obeng, 1986; Arhin et al. 1992).

To begin with, the British colonial government did not have the authority to grant power to the local chiefs to do anything in the first place. To actually grant to the Chiefs that which they naturally had by the 1883 Ordinance to maintain peace and order was therefore acknowledgement of the irrelevance to which the 
chiefs had been reduced to, by the colonial administrators (IEA, 2010: P. 3-4). Notice that although the chiefs of Ghana and the colonial administrators were convinced and, indeed, maintained the alternate reality that; the type of government they practiced over the natives was democratic, it did not possess the key elements of the rule of law as it would be later discussed in this paper.

\subsection{Defining the Rule of Law}

The word 'democracy' is used first to denote a system of government based on rule of law and the observance of civil liberties, where decisions by the state are subject to the deliberations of a majority of the citizens or elected representatives (Desai \& Woolcock, 2012; Dworkin, 1988; Sen, 1990a; 1990b). Desai and Woolcock's systematic review of the rule of law provides more detailed discussion on what the term means in governance and the confusion surrounding the definition and the practice of the rule of law.

Again in this paper, democracy is defined as: "a government by the people where the supreme power of the nation is vested in the people, which is exercised directly or through their elected representatives in a free electoral space and processes, without coercion, intimidation or fraudulent inducement or vote buying, but sustained on a formal principle of ethical governance, equality, civil rights and liberties, justice, autonomy, choice and privileges, with formal system for the administration of justice, retributive justice and reward against deprivation of civil and administrative rights and other forms of punitive reward and recompense".

By the adoption of the above inclusive definition of democracy, the meaning of "Choice" as an ethical value and a vector of autonomy often found within a good democratic space among the functionings of the people, is incorporated in the meaning of democracy.

Democracy is also being used here at times to mean the relationship between man/woman and his/her actions and deeds as well as the choices he/she may make vis-à-vis state action or response to individual initiatives, numerated over government action or response. That is to say, democracy equates freedom of thought, action, and being, which serve as default measure for assessing whether a given government's conduct or rule offers "pain" or "pleasure" to the individual.

In this paper, again, the rule of law within a democracy includes the various norms and conduct as well as the freedoms such as; the freedom of worship, of association, of speech, freedom from unreasonable searches and seizures, choice and general functionings of human beings as autonomous bodies (Dworkin, 1988; Gearey et al. 2009: p. 5-21). The paper borrows the definition for the rule of law from the World Justice Project (2009) due to its specific approach to the concept as its working definition as well. This is articulated as thus:

1) The government and its officials and agents as well as individuals and private entities are accountable under the law.

2) The laws are clear, publicized, stable, and just; are applied evenly; and protect fundamental rights, including the security of persons and property and certain 
core human rights.

3) The process by which the laws are enacted, administered, and enforced is accessible, fair, and efficient.

4) Justice is delivered timely by competent, ethical, and independent representatives and neutrals that are of sufficient number, have adequate resources, and reflect the makeup of the communities they serve.

The United Nations General Assembly defines the rule of law in a broader sense as, "the rule of law and democracy are interlinked and mutually reinforcing and that they belong to the universal and indivisible core values and principles of the United Nations" (UN Chronicler, Vol. XLIX, No. 4, 2012). This definition is not really helpful, but that is what we are given by the august institution.

Freedom of Choice in the most simplistic term means the ability to decide for oneself what one wishes to do, eat, drink, buy, study or not do anything, so long as one's choice does not interfere with the right of another person. In principlebased ethics, "choice" may be analysed under the Hohfeldian incident of "rights", "claims", "power" and "privilege" as well as "immunity", to determine the modalities of exercising or not exercising one's choice in relation to those of others (Norman, 2016a; Beauchamp \& Childress, 2001).

This paper would also investigate if the people of Ghana relate to the concept of choice and if so, what is the nature of the relationship.

\section{Method}

\subsection{The Internet and Hand Search Strategy}

The author searched databases such as PubMed, Medline and others for reports, editorials and published papers in the English Language. A search on Goggle Scholar on "Democracy in Africa" yielded over 77 million entries and "Rule of Law and Democracy in Africa" yielded close to 21 million with "Rule of law and Democracy in Ghana" yielding over 714,000 entries. Additional Internet search was conducted, with hand searching of grey literature produced by the Government Printers, Ministry of Interior, Ministry of Local Government, Ghana School of Law Library, University of Ghana, Legon, Accra, Ghana Law School, High Street, Accra, Ghana for the same titles.

The search was broken into three main thematic areas: Democracy in Ghana, Socio-Cultural embed of democratic principles in the norms of the society, Rule of Law to evaluate evidence of democracy, the exercise of choice and the overall capabilities and functionings of the people of Ghana (Barnett, 2009: p. 51-70). It was necessary to also look for historical evidence and to assess how the Gold Coast, now Ghana behaved during important moral and ethical challenges such as the slave trade, issues of due process and the administration of justice. The paper also sought to validate the assertion there is a brand of democracy that is patently either Ghanaian or African. The author asserted that there is only type of universal democracy for so long as the African man is considered part of the universal man. Therefore the democracy practiced in Ghana or Africa ought not to be different from the democracy that is practiced in Canada, for example. 


\subsection{Inclusion and Exclusion Criteria for the Assessment of Effects}

The author adopted strict inclusion criteria for the papers reviewed for this article. As much as 240 papers were briefed by the author and four research assistants out of the initial figure of 400,000 articles, opinions, blogs, grey literature and policy documents identified. Out of these only 82 publications met the inclusion criteria and marked for additional review, briefing and re-analysed for this paper, until saturation was reached. Each of the 84 papers was assigned an overall score. A score of: 1 = Entirely Relevant (ER); 1/2 = Somewhat Relevant (SR); and $0=$ Not Relevant at All, (NRaA) against the themes used in this paper. The selected papers were rated and the papers that received scores above 2.5 out of 4 in this evaluation were further analysed for specific linkages and relationships or as rebuttal evidence. The findings were summarized into their respective units, and interpreted them based upon the author's skills and knowledge in ethics, policy, sociology, public health and law. The author excluded papers and reports that did not provided empirical data or analytical reports or studies on democracy, the rule of law and governance. This exercise was purely a desk top review of published literature. No Epidemiological investigation was conducted.

\section{Result and Discussion}

\subsection{Evidence of Democracy Embed in the Historical Culture of the People}

Between 1450 and 1500, West Africa had had well established system of government as shown by the various empires that rose and fell in the sub-region, including the Dahomey, Songhai, Mali and Ghana empires. The first Europeans, Spaniards, were reported to have come to the West African coast in the first instance. The Portuguese followed the Spaniards in the 1500 (Arhin et al. 1992; Obeng, 1986). Although West Africa with the rest of the sub-region is reported to have run and managed well established government, it was devoid of democracy as we know it today. Democracy like morality has a universal quality which is non-modifiable by economics, the level of development by a nation, per capita income, or even the wellbeing of that nation's people. Democracy as defined in this paper and elsewhere is more than mere good governance and the wealth of a nation. In the era gone by, despite the human rights ideals expressed in the Magna Carta of 1215 or its revised version of 1225, the Gold Coast and then Ghana did not ordinarily respect the civil liberties of its people for themselves but rather for the good of the society. The colonial administrators although aware of the Magna Carta, did not consider the natives as "free men" who deserved better treatment, and who had access to fair trial, freedom of speech, and freedom from taxation without representation like similar men in the United Kingdom (Ray, 1976). Ray (1976) offered additional light on this thought that regarding the sanctity of the African person and to whom certain inalienable rights were to have attached:

African philosophy tends to define persons in terms of the social group to 
which they belong. A person is thought of first of all as a constituent of a particular community, for it is the community which defines who he is and who he can become ... To this extent, African thought acknowledges the transcendence of individuals over their own sociocultural conditions. However, the emphasis upon a person's individuality and freedom is always balanced against the total social and historical context ... Different societies, of course, conceive of these elements in different ways, but the moral ideal is generally the same-the harmonious integration of the self with the world (Ray, 1976: p. 132).

If one is not fully acknowledged essentially as a man independent of his social and historical circumstances, then one cannot also be extended with certain rights, freedoms and privileges. Granted, there was a modicum of due process in Africa under its traditional system of governance. For example, in the trial of cases before the chief and his elders, one was allowed to cross examine witnesses, interrogate one's accusers, but one was not free from self-incrimination, and no criminal ever was read his or her so-called, "Miranda rights". One was guilty until one could prove otherwise. The administration of justice was driven by considerations of irrelevant factors to the substantive claims of culpability. Some of those factors considered in weighing relative responsibility of the parties to an issue, were the prestige of the accused or the accuser, the wealth status of the accused or accuser, and general inequities modified by age, tribe or ethnicity and influence (Boahen, 1966). It was assumed that if one was from a prominent home, if one was an older person with wealth and multiple wives, then such a man could not be accused of, for example, rape of a minor because such an act was "beneath" such a man or the man was "above" such an act. The "beneath and above" tool for the evaluation of culpability led to the denial of justice to many a victim (Ray, 1976: p. 104-106). For example, the issue of rape of minors by older adult men until the late 1980's was totally unheard of phenomenon, an unreported crime in Ghana. It is not that the crime was not happening but because the society of Ghana was in denial that an older man in his 50 's, 60 's, and even 70 's would choose to rape a girl of say 10,12 , or 15 years of age or younger. Even if it were accepted that the older man may have had carnal knowledge of the minor, previously, the minor was accused as 'asking for it', or in the local parlance and to paraphrase, 'she presented herself to be so used (Ankomah, 2001). Such rationalization of turning the victim into the perpetrator of sex offenses, continues to be noticed in sexual harassment cases, at least, in Ghana even today, when the charge is made against a prominent university lecturer, or elder in faith-based organizations and in other industries (Norman et al. 2012a, 2012b, 2013).

Despite this observation, democracy, although a topic that was probably for discussion in European cities and intellectual circles, was not being spoken about in Africa south of the Sahara in the 1400s and even 1900s in the same way that society now discusses the issue, a fact borne out by the cultural and historical 
circumstances of the era (Fleck \& Hanssen, 2002).

What was happening in the hot tropical clime was something more sinister, something which was anti-human and antibrotherly love. In 1450 when the Spaniards and the Portuguese came to the coast of West Africa, and to the Gold Coast, Caucasian explorers who also doubled as missionaries came with the intention of spreading the Bible's message of brotherly love, equity and fairness based on the principles of equality. By 1460 the main goal of being in West Africa and Africa as a whole, which was about the conversion of the natives from animism to Christianity, was replaced by greed and avarice. Ferocious avarice overpowered the Gospel of Jesus Christ and the Bible, indeed, even God. The missionaries formed slave trading companies that carried slaves from the West African coast into Europe and the Caribbean and the returns from slavery were being invested in education, infrastructure in education and teacher training colleges (Boahen, 1966). By this time, the Christian missionaries had become the new ethnocentric collaborators, who did not only actively participate in the slave raiding, killing, rape, pillage and capture, but provided the guns, ammunitions and the drug of choice of slave raiders: alcoholic bereaves namely, whiskey, Schnapps, gin and tobacco. The trade was fuelled by the Colonialists need for cheap labor. It was also fuelled by the sheer bestiality of the new terrorism of that era, coupled with an intellectual philosophy that black lives did not matter then (and even now among some circles). With the conflation of such events, slavery became the new gospel which quickly made men of God drop their Bibles in favour of the sale of human beings for profit (Combs et al. 1995; Burton, 1984).

By 1460, between 700 and 800 slaves from the various West African nations were being exported to Portugal yearly, which eventually increased in number beyond the wildest estimation of even the African slave raiders themselves. Needless to say, business was good for the raiders and the middle men and women at the coast, the operators of the bonded warehouses (the Castles operators and keepers) and slave shippers and ship owners and crew, and finally, the slave merchandisers at the ports of discharge. The terror that was unleased by the raiders undermined agricultural activity. Farmers were afraid to go to farm, and hunters were equally afraid to go into the wild to hunt. This led to food insecurity and high pricing. Larger families began to even sell some of their own members to the raiders in order to raise capital for the maintenance of the rest. Perhaps, families such as that of the author and others were active, unabashed and ethically immoral participants in the slave trade (Boahen, 1966: p. 108). During this time, there was sporadic raids, killing, raping, seizures, capture, sometimes with entire villages being set ablaze to flash out those who may be hiding. This led to the death of many innocent people, including children, infants, the aged and the infirm who could not outrun the raging fires or the alacrity of the slave raiders wooden clubs and wrought iron shackles (Boahen, 1966).

Slave raiding and slave trade are two dependent crimes for which the Gold Coast, now Ghana has not convincingly apologized, or recompensed the victims or their descendants. 
But the willingness with which the people of the Gold Coast and of Africa participated in the slave trade, shows that respect for civil liberties, for human rights, for autonomy, choice and freedom were not part of the intrinsic values of life in the Gold Coast, now Ghana. If by nature, these values (choice and freedom) were part of the core moral values of the people of Africa, slavery would not have occurred, because the entire enterprise would have been repugnant to them. The fact that whole human beings in their millions were captured and exchanged for tobacco, alcohol, mirror, and money tells one that the Africans were very happy participating in this trade and brokering their prisoners, neighbours and even relatives. In the process, it was the Africans themselves who cemented in the consciousness of the people of the world that, black lives did not matter. The fact that nations like Spain, Portugal, Britain, the United States of America, Brazil and Argentina participated in the infamous trade does not diminish the role of the people of the Gold Coast, now Ghana. It is a fact that in those days (and as we have seen in some nations even today) many of the Caucasian members of these nations held black people in esteem which was at par with the esteem they held for children (Austin, 2004). Therefore, their exuberance in the slave trade was consistent with the then prevailing perception of who a black person was. Some of these people still hold black people in the same low status as their ancestors did more than 500 years ago up till this day (Brown v. Bd. of Educ., 1954; Plessy v. Ferguson, 1896; Lowery, 2016; People Who Care v. RockfordBd. Of Educ., 1997; Fuller v. Decatur Pub. Sch. Bd. of Educ., 2000; affd, 2001; Parker v. Trinity High Sch., 1993).

As some politicians in the various African nations pursue or practice "grow your stomach" politics today, where they become pot-belly fat from conspicuous consumption, the African slave raiders and traders were only interested in the meagre revenues they got for selling their brothers for money. They bought the then delicacies like rice, flour for baking bread, mirrors to admire their faces, trinkets to adorn themselves and alcohol to dull their conscience. The wholesale participation of African slave raiders in the trade only cemented the prejudices of the European and American slave traders and dealers against all Africans that the African's place in the world did not confer on him an iota of democratic privileges and rights (Lowery, 2016; Plessy v. Ferguson, 1896).

The current under-performing economies which is overseen by African Governments, an economic system which denies the majority of the people the right to compete in the market place, the right to full and gainful employment, the right not to be poor and live in squalor, the right to good housing and education, and to income at the end of a productive enterprise, the right to be respected by his or her leaders - all point to the fact that black lives do not matter today in Africa and democracy is yet to be understood (Mattes and Bratton, 2007).

African government leaders appear to have reached the conclusion that the populations they rule over are not worth the good life and opportunities. These governments seem to have created the conditions to ensure the recurrence of every imaginable bad opportunity. This leads to large migrations (as part of the 
reaction to deprivation) to Europe and other well-organized nations with respect for human rights, which re-enforces the reality that black lives do not, indeed, matter in Africa. Because black lives do not matter much in Africa, it cannot matter much anywhere else. The lack of individual liberties, autonomy and equal opportunity to participate in the respective nations' cake, reinforces the feelings of old that even modern day African leaders still look at their people as second class humans who deserved to be cheated and whipped, if not literally, then figuratively, and disrespected and above all, ignored. And because the majority of Africans are ignorable, the citizens of African nations should not be conferred with democratic privileges and rights since they will do zilch about the situation they find themselves no matter how awful. Others may attribute the lack of inertia on the part of the African to cause change in his own nation, to review non-performing leaderships, to the lack of intelligence of black people (Watson, in Kargbo, 2007). That poverty, chronic stresses and shocks, and general pain and displeasure should be their lot. Looking at the results that have been created by the respective African leaders, the low economic growth, the high unemployment, the economic deprivation, the high incidence and prevalence of preventable diseases of malaria, cholera, typhoid and others, against the outrageous opulence in which the Presidents and their ministers live -one is compelled to read Watson's argument that the Western World should not be optimistic about Africa becoming an economic success because, when it comes to Africa, the West's "social policies are based on the fact that Africans intelligence is the same as ours-whereas all the testing says not really". The record of Africa's leaders appears to support Watson's racist assessment.

\subsection{Slavery: What Led to Its Cessation?}

Among the arguments advanced to explain the abolitionist movement against slavery has two prongs: an economic and innovative argument and humanitarian one. The miraculous emergence of machines to drive the industrial revolution and the convergence of new approaches to running economic systems in the United Kingdom, Europe and the United States of America and Canada, rendered slavery progressively unprofitable and could have still been a part of everybody and everyday life but for those developments (Maxine Berg \& Pat Hudson, 1992).

There has been a great deal of controversy over the circumstances which led to the abolition of the slave trade. Some attributed the abolition of the slave trade to purely humanitarian or moral and religious considerations. But others have argued that the slave trade and slavery were abolished mainly for economic reasons: because it became more profitable to seek in West Africa raw materials and markets rather than slaves ... It seems that slave trade and slavery were abolished for both humanitarian and economic reasons (Boahen, 1966: p. 114).

The abolitionist movement coinciding with the advent of machines and in- 
dustrialization, which redirected the attentions of the missionaries and their surrogates, to return to their original purpose of proselytizing the so-called "primitive natives", was no accident or even a particularly difficult moral choice (Gearey et al. 2009). The advent of machines and the industrial revolution made the cost of carrying so many manual slave workers on hand too prohibitive to be sustainable.

By 1730 and 1750 at the break-out of the pursuit of industrial efficiencies assisted by increased food production, cheap availability of mineral and other resources, stable revenue creation due to increased population and markets, and the introduction of machines provided the impetus. With these advances, soon the employment of machines to increase productivity to meet the needs of the growing population had begun to replace man in the factories. This development put a dumper on the demand for labor including black labor in the sugar plantations in the Caribbean and Brazil, in South and Central America (Maxine Berg \& Pat Hudson, 1992). With the high productivity achieved through the use of machines, the plantations were confronted with over supply and low demands for sugar and other goods produced not only in the colonies, but in the main lands (Boahen, 1966).

The humanitarian argument, was perhaps, galvanized around the Zong affair and other similar inhumane treatment of slaves on plantations in the colonies and in transit. The voyage of the "Zong", a slave trading ship from Liverpool captained by Luke Collingwood set sail in 1791 with 470 slaves from the West African coast line. By the time the ship got to its destination, and under the command of the captain, 132 slaves had been thrown into the ocean to die. The reasons were the suspicion that they may not have made the journey to the end, the slave owner was going to lose money and the ships supplies were getting low, especially, water (Gearey et al. 2009). By jettisoning the slaves into the ocean, dead or alive, or certainly weakened by the voyage, then the ship owner could recover under its insurance cover. The sheer wickedness, with which the Captain, his lawyers and the all-white jury that heard the first case on the insurance claim applied to the matter, simply was too much for the usually ambivalent Christian majority in European and America to take. This might have led to the awakenings of consciousness among the slave owners, beneficiaries of the slave owners' industries and others with no slave owing interests (Gearey et al. 2009).

Deadly voyages have bedevilled West Africa for a considerable length of time. On 24 October 1992 seven Ghanaians and another who was already on the ship, MC Ruby, a Bahamian flagged, Ukrainian crew cargo ship, from Douala, Cameroon, were found hiding in the ship's hold. The ship had docked in Takoradi, in the Western Region of Ghana to take a load of cocoa. The stowaways had wanted to travel to Europe in pursuit of greener pastures. Six days into the voyage, the group's water container was broken, forcing them to begin ferreting about the ship in search of more. This resulted in them being discovered by the ship's crew. Members of the ship's crew took all of the group's money and then confined them in the compartment containing the ship's anchor chain. They were 
held there for three days, being given no food and little water. Eventually, the six crew members began removing the group two to three at time. Although they told the men that they were being moved to a more comfortable accommodation, the crew in fact had decided to murder the men, beating them with an iron bar and shooting them, then finally throwing them overboard somewhere off the coast of Portugal. It was later determined that the crew members' motive was to avoid the heavy fine they would have faced for bringing illegal immigrants into a Western port (Davies, 2007; French, 1996; Whitaker, 1995; Nundy, 1994; Adams, 2007).

\subsection{Precedential Evidence of Democracy in Ghana}

In the case of Ghana, the first general elections in its nascent attempt towards building a democratic nation was held in 1951. Until this time, there was the Central Government rule, which had been in practice by the colonial administration since the so-called Bond of 1844. Despite the bond, the natives did not have much of an experience for parliamentary system of government. When on the eve of independence the first parliamentarians prepared to sit to do the business of government, those newly elected parliamentarians could not have understood the nature and the burden of responsibility that were placed on them. They were all rookies to both the democratic dispensation and the rule of law (Fanon, 1986). What they were familiar with, was the traditional African system of chieftain government, where slaves, indentured servants, women and children did not have equal rights as the adult male members and rules of evidence were not observed by either party.

With the exception of the nations in North Africa that were independent, Liberia in West Africa with South Africa in the Southern part of the continent, both also independent, Ghana had no peer nation from which it could even learn the art of governance (Boahen, 1966). The new parliamentarians were cut off from North Africa by language, Arabic, and from South Africa by the Apartheid system. Although Liberia as a colony was 'founded' by freed slaves from the United States, their system of government was vastly different from that of the British colonies and was not in a position to mentor those new parliamentarians in Ghana (Cassell \& Abayomi, 1970; Catt, 1999: p. 9; Saye, 1977; Adam, 1983; Adam and Marion, 1980). At this moment, democracy did not have much of an experiential effect or impact on the philosophy of government or of governance in Sub-Saharan Africa let alone, Ghana (Fayemi, 2009).

There were different colonial administrative systems, which did not enable the colonies the chance to learn from each other. The British practiced a remotecontrol system, (Indirect rule), with local surrogates such as the chiefs, local strong men and appointees of the colonial governor (IEA, 2010).

The French had the system of colonial governance called 'Assimilation', which was an extension of the French social integration concept of social inclusion. They were bent on transforming the colonial African, a desire which continues today, into French men and women, with language, mannerism, eating habits and all as those in France do. For a nation such as France with complex social 
make-up and history of monarchs, aristocracy, intellectuals and free-thinkers, the policy of Assimilation was doomed to fail from the start. The peoples of the colonies controlled by the French were anything but aristocratic, monarchical, intellectuals and sophisticated (Fanon, 1961). The disparities between the colonials and the nationals during the transitional period post-colonial rule led Fanon to write his famous book, "The Wretched of the Earth", in which he described the new African as the bourgeoisies, (meaning middle class). That is to say,

"the national middle class that took over power at the end of the colonial regime was an under-developed middle class. It had practically no economic power, and in any case it was in no way commensurate with the bourgeoisie of the mother country which it hoped to replace ..." He added that "the national bourgeoisie of under-developed countries was not engaged in production, nor in invention, nor building, nor labor," but rather "canalized into activities of the intermediary type". Its innermost vocation seems to be to keep in the running and to be part of the racket (Fanon, 1961).

The German system of governance was motivated by the national view even then that what was cherished German political trait, must be good for all. As was done in Namibia, the short-lived German territory of Trans-Volta Togoland was being managed as if it were a satellite German space where German language, culture, schools, all things German were being imported into this far out territory, thanks to the Versailles Treaty.

What was common with these three types of colonial government was that the colonies were not being managed on democratic principles. The enclaves of the natives were rather segregated from the colonials. The important jobs were being performed by the colonials with the menial jobs assigned to the natives. It was an environment, where the white man or woman was "primus inter pares", the first amongst equals (Boahen, 1966).

Some of the colonial administrators were not experienced bureaucrats and some were not even good military officers in Britain nor did they possess the pioneering spirit for nation building. For example, George Maclean who became the governor of the Gold Coast in 1829 was reported to be an aimless young man and a mediocre soldier until his appointment (The Gale Group, 2010). Although Maclean is reported to have built a cohesive, and all-inclusive administration within the then British colonial space, it beats the imagination to wonder why such an achievement could not have quelled the angst, the agitation and disaffection among the nationals who wanted self-rule. The logic contained in this inquiry is internally consistent. If Maclean and his compatriots were good nation builders, the natives would not have actually taken advantage of the lapses in the administration and agitated for self-rule.

\subsection{Participation in the Electoral Process Does not Denote Democracy}

Some researchers and specialists of political science, history and current affairs 
conclude that because the people of the respective African nations are allowed to participate in general elections, (which may or may not be free and fair, where choice of candidates are skewed in favour of one group or the other and therefore denying the people a true democratic participation), the mere ability to cast a ballot is a sign of democracy. Such proponents include Sandbrook et al. (2008), Diamond, Linz and Lipset (1989). The mere participation in the electoral process does not demonstrate that the voters are indeed living in a democratic nation. There are however many of the political operatives in Ghana and elsewhere would have the unsuspecting national voters think that somehow by voting, they are indeed, participating in democracy. The voting environment is fraught with deceit and arm twisting, vote buying and tribalism so much so that, often times and especially in parliamentary elections many voters become apathetic about democracy (Bratton \& Van de Walle, 1997; Santiso, 2001; Carothers, 2002; Fawole, 2005). In such elections, some candidates run without a plan or strategy except the reality of being members of particular clan, kin or clique. For example, in the 2016 presidential elections in Ghana scheduled to take place the ruling party, the National Democratic Congress on December $7^{\text {th }}, 2016$, released its manifesto bit by bit from September $3^{\text {rd }}$ through the $6^{\text {th }}$ when the full document became available to the public, less than three months to the Election Day. The main opposition party, the New Patriotic Party $9^{\text {th }}$ October, 2016, released it for fear of its programs being appropriated by the other party. Charges of appropriation and thus the delay in releasing party manifestos are not new. Each election year, such charges are made against the other party by either leading political parties. If the process was about which football team was hiding its player lists that would be fun. But this is a national general election to choose the president of the nation and members of parliament, which makes it all the more imperative. Such events undermine the democratic process. The delays in putting into the general stream of commerce a document such as the manifesto of political parties, do not allow serious audit of the intentions of the political parties (Gyimah-Boadi, 2000, Beetham, et al. 2008). The delays tend to bastardize the process since the public and the media have nothing substantive to discuss and reduce what could have been deep analyses of policies to personality cult or ethnocentric and tribalistic rah-rah-rah push for power. A political manifesto contains the blue-print of what a party is capable of doing for the people in order for their lives to be improved, if elected. When the intents of political parties are shrouded in secrecy, the very process of voting cannot be said to be purpose driven, transparent, and accountable. Even though these words fall out of the speeches of politicians in Ghana very easily, 'transparency, probity and accountability', they do not seem to demonstrate a working understanding of the phrase in many instances (Boafo-Arthur, 2004, 2016). In fact, it has been argued that while there can be elections without democracy, there cannot be democracy without election (Levitsky \& Way, 2002).

The participation in election, the right to compete for a position in the electoral process and the guarantee of civil rights and liberties are the essential ele- 
ments of democracy, in the most simplistic terms (Sen, 1999a; Bratton \& Van de Walle, 1997). But the participation only shows that A or B participated in an election. It does not mean that his or her views on good governance matter to the governing process or that his capabilities and functionings would be enhanced (Sen, 1999a, 1999b).

\subsection{The Lack of African Philosophers on Democracy Defeats Claims of African Democracy}

It has been noted that African traditional authority or governance was not essentially based on democracy but on hierarchy, virility, wealth status, age and social standing (Edigheji, 2005: p. 6). African societies have existed for thousands of years under various monarchical empires and kingdoms. With the exception of the pre-eminence of Timbucktu in the Mali and Songhai empires in the 1400, and even raised an allegedly world class university, we have not profited from the scholarship and philosophical work of the intellectuals that may have taught at this institution. This and other cases make it difficult for Africa to boast of philosophers that promoted and considered a system of governance which Africa should follow or adopt (Edigheji, 2005: p. 9). Democracy as a system of governance and a way of life appears to be a recent addition to governance in Africa and in the respective nations (Edigheji, 2005: p. 9). It is only now that revisionist African philosophers are redefining the philosophical discourse for democracy. The attempt so far has shown that the adopted modern system of governance in Africa is not yielding the results the respective national populations want. Some African historians have cast blame for the paucity of African philosophers on the triple legacy of Colonialism, Christianity, and Islam (Mazrui, 1967). Others have contended that Africa's philosophies were reposed in the chiefs and elders and so to the extent that Africa had chiefs and elders, Africa also had philosophers (IEA, 2010). This paper finds such arguments circular and unhelpful to the simple question of whether or not Sub-Saharan African had political philosophers like Aristotle, Rousseau, Adam Smith, Mills, Kant, and even now, luminaries like Seers, Myrdal, Sen, and Nussbaum? If Africa had such thinkers in the past, then it should have such philosophers today and in abundance.

\subsection{Absence of Evidence of Respect for Civil Liberties in the Normative Culture}

Democracy as a system of governance and nation building is raised on the principle of equality of man, freedom, justice, choice among other civil liberties. If equality of man was a hallowed principle in Africa, it would have been part and parcel of the way of old and the modern life of the people. If Africa respected the right of autonomy of its people, it would have reflected and refracted as the translational strands and labyrinths of thought and conduct. It would been revealed in the cacophony of lyrics and songs of the youth and in the cadences of dance and walkabouts of all (Evans, 1995; Johnson, 2004; Wade, 1990; Weiss, 
1998). If the civil liberties of the people of Africa mattered, concerns to empower $60 \%$ of the populations that live on less than US\$1.85 a day out of entrenched poverty, systemic corruption and poor performing government systems would have been integral parts of the consciousness of Africa's leadership, of national policies and economic performance from one government to the other and from one leader to the other (NPP Manifesto, 2012, 2016; NDC Manifesto, 2012, 2016).

\section{Conclusion}

Ethical leadership requires that governments and other leaders in business and industry would be responsive to the needs of the people and that whatever they do on behalf of the public and for the public would be beneficial and gainful to the public. In order for government leaders and those in business and industry and in education to appreciate how to work the very reality of democracy and choice making into their mundane, day to day dealings with others, they have to first understand that democracy is not an action to be made real on Election Day only. It is an action which is manifested every day, in the policies, in the rules and regulations and, in the job assignment and performance review and evaluation of the population. Democracy is not only a function of politics and governance. Democracy is the action which lies in the crevices of human conduct and creates congenialities between the linkages and dealings of ordinary people and; in how they perform their functions, how they demonstrate responsibility and accountability; and how they relate to the common interests and goals of the groups and societies to which they belong. It is the duty of government and other leaderships; it is the duty of husbands and wives, of mothers and children; it is the duty of supervisors and bosses to create the enabling environment for choice making, and for the people to live responsible and productive lives within the spirit of freedom, autonomy and choice. When these principles are manifested in the ordinary lives of the people, it becomes easier to internalize and to translate the workings of these principles into governance, leadership, parenthood and even into interpersonal relationships. In nations where there is no democracy, no freedom of choice, no free speech, no freedom of association and of thought and worship, such nations do not generally have dynamic populations that believe in themselves and their abilities. Such nations are often very poor and vulnerable and incapable of handling their own affairs without handout and loans at steep costs to both current and future generations such as the financial liquidity situation of Ghana today. Whether democracy and choice mean anything to the average person in Ghana or elsewhere in Sub-Saharan African can be assessed on how well the populations transfer their dreams into entrepreneurial showcases of productivity, profit and well-being. The reality of their goals can be demonstrated in the value they add to the resources and opportunities; nature may force on them against the choices they ultimately make. Looking at Ghana's democracy from the various foci raised in this paper and set against the way and manner, the fruits of democracy are translated into the lives 
of the people; it is difficult to say if the population is able to relate to democracy as a living concept of freedom, choice, well-being and doing in their personal lives. Unless the people are able to interpret democratic principles on a personal basis and internalize such into their doings and functionings, it would remain an abstract concept, which may be fitting for foreigners, for westerners, for upwardly mobile nations, but not good for self-described and self-absorbed poor and financially vulnerable nations such as Ghana.

\section{References}

Abdul, K. (2007). Black People are Less Intelligent, Says Dr. James Watson, Nobel Prize Winner and DNA Pioneer.

https://mightyminnow.wordpress.com/2007/10/18/black-people-are-less-intelligent-sa ys-dr-james-watson-nobel-prize-winner-and-dna-pioneer/

Adams, B. (2007). Letters: What Happened after Deadly Voyage. The Guardian.

Ankomah, A. (2001). Ghana. In R. T. Francoeur (Ed.), The International Encyclopedia of Sexuality (p. 519). New York, NY: Continuum.

Arhin, K., \& Afari-Gyan, K. (1992). The City of Kumasi: Past, Present and Future. Accra: Institute of African Studies.

Austin, R. (2004). Back to Basics: Returning to the Matter of Black Inferiority and White Supremacy in the Post-Brown Era. The Journal of Appellate Practice and Process, 6, 78-99.

http://lawrepository.ualr.edu/appellatepracticeprocess/vol6/1ssl/7

Barnett, H. (2009). Constitutional and Administrative Law (7th ed.). Abington: Routledge-Cavendish, Taylor \& Francis Group.

Beauchamp, T. L., \& Childress, J. F. (2001). Principles of Biomedical Ethics (5th ed.). Oxford: Oxford University Press.

Beetham, D., Carvalho, E., Landman, T., \& Weir, S. (2008). Assessing the Quality of Democracy: A Practical Guide. Stockholm: International Institute for Democracy and Electoral Assistance. http://www.idea.int

Berg, M., \& Hudson, P. (1992). Rehabilitating the Industrial Revolution. The Economic History Review, 45, 24-50. https://doi.org/10.2307/2598327

Boafo-Arthur, K. (2004). Voting for Democracy in Ghana, the 2004 Elections in Perspective, Constituency Studies (Vol. 2).

Boafo-Arthur, K. (2016). Voting for Democracy in Ghana, the 2004 Elections in Perspective, Constituency Studies (Vol. 1).

Boahen, A. (1966). A Short History of Ghana. London: Heinemann Press.

Bratton, M., \& Van de Walle, N. (1997). Democratic Experiments in Africa: Regime Transitions in a Comparative Perspective. Cambridge: Cambridge University Press. https://doi.org/10.1017/CBO9781139174657

Brown and Board of Education (1954). 347 U.S. 483.

Burton, J. H. (1984). Local Authority Finance. London: Account and Auditing London Gee and Corporation Ltd.

Carothers, T. (2002). The End of the Transition Paradigm. Journal of Democracy, 13, 5-21. https://doi.org/10.1353/jod.2002.0003

Cassell, \& Abayomi, C. (1970). Liberia: History of the First African Republic. New York, NY: Fountainhead Publishers.

Catt, H. (1999) Democracy in Practice. London: Routledge. 
https://doi.org/10.4324/9780203270240

Combs, H. M., \& Jenkins, D. E. (1995). Public Sector Financial Management. Oxford: Chapman and Hall.

Davies, N. (2007). The Cruellest Voyage. The Guardian.

Desai, D., \& Woolcock, M. (2012). The Politics of the Rule of Law Systems in Developmental States: Political Settlements as a Basis for Promoting Effective Justice Institutions for Marginalized Groups. Manchester: Effective States and Inclusive Development Research Centre (ESID), School of Environment and Development, University of Manchester. http://www.effective-states.org

Diamond, L., Linz, J. J., \& Lipset, S. M. (1989). Democracy in Developing Countries. Boulder, CO: Lynne Rienner.

Dworkin, G. (1988). The Theory and Practice of Autonomy. Cambridge: Cambridge University Press. https://doi.org/10.1017/CBO9780511625206

Edigheji, O. (2005). A Democratic Developmental State in Africa? A Concept Paper. Johannesburg: Center for Policy Studies.

Evans, P. (1995). Embedded Autonomy: States and Industrial Transformation. Princeton, NJ: Princeton University Press.

Fanon, F. (1986). Black Skin, White Masks. (Trans. C. Lam Markmann). London: Pluto.

Fanon, F. (1961). The Pitfalls of National Consciousness, Chapter 3, the Wretched of the Earth. https://www.marxists.org/subject/africa/fanon/pitfalls-national.htm

Fawole, A. (2005). Voting without Choosing: Interrogating the Crisis of "Electoral Democracy" in Nigeria. In L. Kasongo, Liberal Democracy and Its Critics in Africa: Political Dysfunction and Struggle for Social Progress (p. 150). London: Zed Books.

Fayemi, A. K. (2009). Journal of Philosophical Association of Kenya, 1, 101-126.

Fleck, R. K., \& Hanseen, F. A. (2002). The Origins of Democracy: A Model with Application to Ancient Greece. Bozeman, MT: Department of Agricultural Economics and Economics, Montana State University.

French, H. W. (1996). TELEVISION: Into Africa to Tell an Unlikely Tale of Survival. The New York Times.

Fuller and Decatur Public Schools Board of Education (2001). 78 F. Supp. $2 d 812$ (C.D. Ill. 2000), aff d, 251 F.3d 662 (7th Cir.).

Gearey, A., Morrison, W., \& Jago, R. (2009). The Politics of the Common Law. Abingdon: Routledge-Cavendish.

Saye, G. J. (1977). Liberian History before 1857. Hicksville, NY: Exposition Press.

Gyimah-Boadi, E. (2000). The December 2000 Elections and Prospects for Democratic Consolidation. In J. R. A. Ayee (Ed.), Deepening Democracy in Ghana (Vol. 1). Accra: Freedom Publications Ltd.

Institute of Economic Affairs (IEA) (2010). The Role of Traditional Rulers in Governance. Accra: IEA.

Johnson, R. (2004). Kant's Moral Philosophy. The Stanford Encyclopaedia of Philosophy. http://plato.stanford.edu.archives/sum2014/entries/kant-moral/

Adam, J. (1983). From Slaves to Palm Kernels: A History of the Gallinas Country, West Africa. Wiesbaden.

Adam, J., \& Marion, J. (1980). Slaves from the Windward Coast. Journal of African History, 21, 17-34.

Levitsky, S., \& Way, L. A. (2002). The Rise of Competitive Authoritarianism. Journal of Democracy, 13, 51-65. https://doi.org/10.1353/jod.2002.0026 
Lowery, W. (2016). Mapping Police Violence.

Mattes, R., \& Bratton, M. (2007). Learning about Democracy in Africa: Awareness, Performance, and Experience. American Journal of Political Science, 51, 191-217. https://doi.org/10.1111/j.1540-5907.2007.00245.x

Mazrui, A. (1967). On Heroes and Uhuru-Worship: Essays on Independent Africa. London: Longman.

National Democratic Congress (2016). Manifesto. Accra: Assembly Press.

New Patriotic Party (2012). Manifesto. Accra: Assembly Press.

New Patriotic Party (2016). Manifesto. Accra: Assembly Press.

Norman, I. D. (2016a). Desperately Seeking the Tools of Ethics for Traditional Medicine Practice. Advances in Applied Sociology, 6, 255-260.

Norman, I. D., Aikins, M., \& Binka, F. N. (2012a). Traditional and Contrapower Sexual Harassment in Public Universities and Professional Training Institutions of Ghana. International Journal of Academic Research, 4, 85-95.

Norman, I. D., Aikins, M., \& Binka, F. N. (2012b). Faith Based Organizations: Sexual Harassment and Health in Accra-Tema Metropolis. Journal of Sexuality and Culture, 14, 1-15.

Norman, I. D., Aikins, M., \& Binka, F. N. (2013). Sexual Harassment in Public Medical Schools in Ghana. The Ghana Medical Journal, 47, 1-13.

Nundy, J. (1994). Stowaways "Killed and Thrown Overboard”. The Independent.

Obeng, E. E. (1986). Ancient Ashanti Chieftaincy Tema. Accra: Ghana Publishing Corporation.

Parker and Trinity High School (1993). 823 F. Supp. 511 (N.D. I11.).

People Who Care and Rockford Bd. of Education (1997). 111 F.2d 528, 538 (7th Cir).

Plessy and Ferguson (1896). 163 U.S. 537.

Raaflaub, K. A., Ober, J., \& Wallace, R. W. (2007). Origins of Democracy. Los Angeles, CA: University of California Press.

Ray, B. C. (1976). African Religions: Symbols, Ritual and Community. Englewood Cliffs, NJ: Prentice Hall, Inc.

Sandbrook, R., Edelman, M., Heller, P., \& Teichmark, J. (2008). Social Democracy in the Global Periphery: Origins, Challenges, Prospects. American Journal of Sociology, 114, 832-834.

Santiso, C. (2001). International Cooperation for Democracy and Good Governance: Towards a Second Generation? European Journal of Development Research, 13, 154-180. https://doi.org/10.1080/09578810108426785

Sen, A. (1999a). Democracy as a Universal Value. Journal of Democracy, 10, 3-17. https://doi.org/10.1353/jod.1999.0055

Sen, A. (1999b). Development as Freedom. Oxford: Oxford University Press.

Sorenson, G. (1993). Democracy and Democratisation: Process and Prospects in a Changing World. Boulder, CO: Westview.

The Gale Group (2010). Maclean.

UN Chronicler (2012). Rule of Law and Democracy: Addressing the Gap between Policies and Practice. The Declaration Adopted on 24 September 2012 by the United Nations General Assembly. https://unchronicle.un.org/article/rule-law-and-democracy-addressing-gap-between-p olicies-and-practices

Wade, R. (1990). Governing the Market. Princeton, NJ: Princeton University Press. 
Wallace, R. W. (2007). Revolutions and a New Order in Solonian Athens and Archaic Greece. In K. A. Raaflaub, J. Ober, \& R. W. Wallace (Eds.), Origins of Democracy. Los Angeles, CA: University of California Press.

Weiss, L. (1998). The Myth of the Powerless State. Cambridge: Polity Press.

Whitaker, R. (1995). Life Terms for Stowaway Massacre. The Independent.

World Justice Project (2009). The Rule of Law Index. World Justice Forum II, Vienna. http://worldjusticeproject.org/publication/rule-law-index-reports/rule-law-index-2009report

Submit or recommend next manuscript to SCIRP and we will provide best service for you:

Accepting pre-submission inquiries through Email, Facebook, LinkedIn, Twitter, etc. A wide selection of journals (inclusive of 9 subjects, more than 200 journals)

Providing 24-hour high-quality service

User-friendly online submission system

Fair and swift peer-review system

Efficient typesetting and proofreading procedure

Display of the result of downloads and visits, as well as the number of cited articles

Maximum dissemination of your research work

Submit your manuscript at: http://papersubmission.scirp.org/

Or contact aasoci@scirp.org 